\title{
AN APPRAISAL SYSTEM FOR MONITORING PERFORMANCE OF CONVENIENCE STORES IN TAIWAN
}

\author{
W.Y. Wu ${ }^{1}$, C. Bai ${ }^{2}$ and O.K. Gupta ${ }^{3}$ \\ 1,2Department of Business Administration \\ National Cheng Kung University, Taiwan \\ ${ }^{1}$ wanyi@mail.ncku.edu.tw, ${ }^{2}$ cj.bai@msa.hinet.net \\ ${ }^{3}$ College of Business \\ University of Houston Downtown, USA \\ guptao@uhd.edu
}

\begin{abstract}
With service industries achieving almost $70 \%$ of GDP, Taiwan has witnessed a major shift in its economic structure, similar to the trends that have been observed elsewhere. The retail sector has shown enormous growth, and Taiwan has seen tremendous growth in convenience stores in recent years, as their density has peaked in many Asian countries. Operating efficiency has become a critical element of success and survival for convenience stores in a highly competitive environment. In this paper, we apply Data Envelopment Analysis (DEA) and the Malmquist Productivity Index (MPI) to investigate the productivity efficiency and monitor the performance of convenience stores, characterized by multiple inputs and outputs. The paper also offers a distribution service system model and management matrix to examine the competitiveness of the store chain as a whole. The findings indicate that DEA can provide useful diagnostic information, and suggest ways to improve efficiency.
\end{abstract}

\section{OPSOMMING}

Die bydrae tot die BBP van Taiwan beloop tans bykans $70 \%$ ten opsigte van dienstebedrywe. Die kleinhandelsektor toon ook ' $n$ betekenisvolle oplewing. Doeltreffendheid is ook van opperste belang vir geriefswinkels.

Die navorsing ondersoek die gebruik van DataOmsluitingsAnalise (DOA) en die Malmquist Produktiwiteits-Indeks om die vertoning van geriefswinkels met veelvoude van insette en uitsette te monitor. Die mededingendheid van ' $n$ kettingwinkel word ook bepaal. Toepassing van die bogenoemde DOA-metode lewer nuttige diagnostiese inligting wat gebruik kan word vir verbetering van bedryfsrendement.

\footnotetext{
${ }^{1}$ Corresponding author
} 


\section{INTRODUCTION}

Due to the forces of economic development and social transformation, the focus of Taiwan's industrial structure has gradually shifted from manufacturing to service. The proportion of output value of service trade to Gross Domestic Product (GDP) has increased year by year; in 2004 it was reported to be $68.6 \%$ of GDP (Chen [1]). This phenomenon is similar to many advanced countries. According to a consumer shopping behaviour survey report by AC Nielson in 2005, the number of convenience stores in Taiwan reached about eight thousand in 2004 (Wan [1]). With an average of one convenience store per 2,800 people, this density is perhaps the highest among Asian countries, surpassing Japan's for the first time. The survey also reported that the revenue of individual stores can be affected adversely if the convenience store density reaches more than one per 3,000 people. Therefore the competition among Taiwanese convenience stores has become fiercer in recent years, and store operating efficiency has become a critical factor in the game of survival and success. Donthu et al. [3] argued that many companies have adopted the benchmarking method for improving business processes to achieve higher profits and gain market share. For example, AT\&T, Chevron, American Express, 3M, and other Fortune 500 companies have successfully applied benchmarking in their respective industries (Camp [4]). Not only do large corporations like those mentioned above reap benefits by using benchmarking, but small- and medium-sized companies could also imitate and learn from them to improve their performance (McGonagle et al. [5]).

Donthu et al. [6] proposed a different approach to measuring retail productivity, which is a relative-to-best measure rather than relative-to-average. Thomas et al. [7] postulated that the Data Envelopment Analysis (DEA) method could overcome four concerns by employing efficiency measures: individual store differences, identifying benchmarks, controllable/uncontrollable resources, and conflicting performance outcomes. Barros et al. [8] argued that evaluation techniques developed by companies' human resources divisions in retail stores are rarely perfect. The operational activities that are considered important to achieving improvements are neglected by such techniques. Managers usually rely on financial reports to measure the efficiency of convenience stores. They need an objective 'best-practice' approach that is comprehensive and that fits all stores in the chain. DEA possesses several unique advantages to address the problems and concerns mentioned above.

The purpose of this paper is to evaluate the efficiency of intra-chain convenience stores by applying the Data Envelopment Analysis (DEA). Retail productivity is essentially measured as a ratio of output to input (Bucklin [9]; Ratchford et al.[10]; Ratchford et al. [11]). A higher ratio of measured output to measured input factors can be directly interpreted as higher productivity (Donthu et al. [6]). The output-to-input ratio is popular in the literature, but it has been developed as a macro tool. Besides, there are several other problems in assessing retail productivity (Parsons [12]; Thurik [13]; Kamakura et al. [14]). First, labour (or salesman) productivity has been regarded as retail productivity due to its labour-intensive nature (Ingene [15], Ingene [16]; Thurik et al. [17]; Bush et al. [18]; Stern et al. [19]). Many factors influence productivity, such as scale, age, location, and trading area variables, not typically captured by the output-to-input ratio (Doutt [20]; Lusch et al. [21]; Ratchford et al. [11]; Thomas et al. [7]). Second, as argued by Parsons [12], best practice should be used as the basis for store comparison, not average performance. The input/output ratio is based on averages computed by the least squares regression (Thomas et al. [7]). Finally, taking multiple inputs and outputs into consideration at the same time, the weights of criteria should be different in order to reflect the measure units as well as the relative significance. It would be problematic to arrive at the weights of the varied factors, such as product mix and service levels (Parsons [12]; Thomas et al. [7]).

The organisation of this paper is as follows. In the next section, we provide a literature review of the service distribution model, DEA, and Malmquist Productivity Index. It is followed by a section on research methodology. We then present the empirical results on 20 convenience stores in a chain in Taiwan. Finally, managerial implications and conclusions 
are presented.

\section{LITERATURE REVIEW}

Various constructs of variables have been proposed and used in measuring the output of retailing (Keh [22]). However, it is widely acknowledged that the real output of a retail firm consists of various distribution services (Achabal et al. [23]; Keh [24]). Bucklin's view [9] is that logistical, informational, and product functional services are three major kinds of services in a distribution service model. Betancourt et al. [25] further categorised distribution services into five constructs:

- Accessibility - the level of convenience for consumers to patronise the store.

- Product assortment - includes product lines, and variety within product lines.

- Assurance of product delivery - products are available at the desired time and in the desired form.

- Amount of information - other characteristics of goods and services, such as price and availability, are provided.

- Ambience - the level of store atmosphere is good enough to attract customers.

The distribution services method clarifies the simultaneous viability of various forms of retailing in the marketing channel, such as convenience stores. Due to lack of data, empirical investigations of using the distribution services model have been scarce. However, many researchers have filled a void in this literature by employing macro or micro data in DEA (Betancourt et al. [26]; Donthu et al. [6]; Keh et al. [27]). The DEA methodology is an effective tool for the selection of appropriate input and out variables needed in the distribution service models to calculate the efficiency scores properly.

\subsection{Data Envelopment Analysis (DEA)}

DEA originated in microeconomic production theory, in which a production technology frontier can be constructed by using multiple inputs to achieve the maximum output. Farrell [28] suggested how DEA can provide solutions to possible input-output combinations for actual firms. Charnes et al. [29] applied Farrell's idea in a linear programming format and offered a scalar efficiency measure for all decision-making units (DMUs) to convert multiple inputs and outputs into a single measure of performance.

There have been numerous applications of DEA as an effective performance evaluation tool in many fields, such as manufacturing, schools, banks, pharmacies, small business development centres, nursing home chains, hospitals, police forces, airlines, and so on (Ho et al. [30]). Since the 1990s, several researchers have used DEA to measure the comparative efficiency of retail chain stores. Balakrishnan et al. [31] employed DEA to evaluate the relative spatial efficiency of locations of retail outlets, and showed how the threshold requirements change their spatial efficiency. Athanassopoulos [32] developed a performance-improvement decision aid system for restaurants, based on DEA. Kamakura et al. [14] took four outputs and two inputs into a fuzzy clusterwise translog cost regression to evaluate the efficiency of a commercial bank with 180 branches in Latin America. Li et al. [33] compared three kinds of ownership banks in Taiwan after deregulation in the 1990s by applying a translog distance function DEA. Thomas et al. [7] combined the Delphi approach and DEA to assess the efficiency of a leading US specialist outlet. Donthu et al. [6] analyzed the efficiency of fast-food chain stores using DEA. Keh et al. [27] selected the inputs and outputs metrics based on distribution services theory, which is a three-stage model, and applied DEA to the empirical illustration of the efficiency of a grocery chain store. Barros et al. [8] studied hypermarket retail store efficiency in Portugal using DEA. Donthu et al. [3] used DEA to benchmark a 26-unit fast food outlets' marketing productivity, and provided a set of actionable measures for the improvement of the company's marketing performance. Keh et al. [34] illustrated performance in a chain of hotels in the Asia-Pacific region by incorporating efficiency, effectiveness, and productivity into a triangular DEA model. The results highlighted the crucial role of marketing expenditure in a service organisation. 
Marianna et al. [35] and Wang et al. [36] sapplied a stepwise DEA and four-stage DEA procedure separately to measure a three-star hotel in the UK and international tourist hotels in Taiwan, providing strong evidence that DEA can be used in analysing management efficiency and style in service industries.

DEA is a nonparametric approach to assess the efficiency of homogeneous units such as retail stores (Barros et al. [8]) and uses a 'data oriented approach' (Keh et al. [27]) to evaluate the performance of the individual unit within a given sample. The units are referred to as decision-making units (DMUs). DEA calculates the relative technical efficiency (RTE) of DMUs in a direct way without imposing any functional form on the data. The other distinguishing feature of DEA is that the best performing DMUs are used as the bases for comparison in computing the RTE (Keh et al.[34]). In order to achieve a retailing operation oriented towards excellence, it is important to compare chain stores' performance with that of the best performing DMUs, often referred to as the benchmarking partners. Moreover, unlike a single optimisation for all DMUs in the least square regressions, DEA uses a series of optimisations, one for each DMU, to separate efficient units from inefficient ones. The most efficient retail stores are those stores located on the efficient frontier, similar to isoquants (equal-product curves) of production functions in microeconomics (Donthu et al. [6]). The efficient frontier is a series of points, a line, or a surface connecting the most efficient stores, and is determined by comparing the inputs and outputs of all evaluated stores. Thus DEA produces the relative efficiency boundaries, called envelopes. DEA provides not only an efficiency score for each inefficiency unit, but also provides the target value that would turn an inefficient unit into an efficient one (Rouse et al. [37]).

\subsection{Malmquist Productivity Index}

The Malmquist Index was developed as a dynamic model to assess the total productivity of general economic activities over time in the consumer theory. According to Malmquist [38], a productivity change can be calculated by comparing the inputs of a firm at times $t$ and $t+1$ based on the maximum factor. The input in time $t$ could be decreased so that the firm would continue to produce the same level of outputs at time $t+1$. Caves et al. [39] defined the Malmquist Productivity Index (MPI) as the total factor productivity change from $t$ to $t+1$. Färe et al. [40] combined Caves et al.'s productivity index and Farrell's efficiency concept to construct the DEA-based Malmquist productivity change from $t$ to $t+1$.

The Malmquist Productivity Index (MPI) in the DEA model is defined as the ratio of the efficiency measures for the same unit in two different time periods, or between two different observations for the same period. Measuring between time periods for the same unit is the interest of this paper. This method distinguishes between efficiency changes in technical efficiency and shifts in the efficiency frontier over time by using panel data (Flegg et al. [41]). The MPI is the product of frontier change and efficiency change. The first component is known as the 'frontier productivity index' (FPI), and it measures the relative distance between the frontiers. The second component is known as the 'catching up index' (CIE), and it shows the relative change in efficiency between the periods (Odeck [42]). This index can offer a depth view to managers to monitor the changing trend of each DMU in many service fields (Rouse et al.[37]; Flegg et al. [41]; Li et al. [33]; Chen [43]; Odeck [42]; Şakar [44]).

\section{METHODOLOGY}

In this section, we describe the methodology of our paper. First, we briefly discuss some of the key concept needed for the research.

\subsection{DEA Efficiency Measures}

The DEA efficiency measures were first developed by Farrell [28] and extended later by Charnes et al.[29] and Färe et al. [45]. The general purpose DEA considers n DMUs 
$(\mathrm{j}=1, \ldots, \mathrm{n})$, with $\mathrm{k}$ inputs and $\mathrm{m}$ outputs. Let $x_{i j}, y_{i j}$ denote the observed level of the $\mathrm{k}$-th input and m-th output, respectively, at $D M U_{j}$.

In a ratio form, we have all outputs over all inputs $\frac{u^{\prime} y_{i}}{v^{\prime} x_{i}}$, where $u$ are the output weights and $v$ are the input weights. Assuming constant return-to-scale, the following linear programming is solved to ascertain whether $D M U_{j 0}$ is DEA-efficient and measure its efficiency:

$$
\begin{aligned}
& M A X_{u, v}\left(u^{\prime} y_{i}\right) \\
& \text { s.t. } v^{\prime} x_{i}=1 \\
& v^{\prime} y_{j}-v^{\prime} x_{j} \leq 0, f=1,2, \ldots, N \\
& u, v \geq 0
\end{aligned}
$$

This form is the multiplier form of the linear programming model. We usually use the dual that has the following form:

$$
\begin{aligned}
& M A X_{\theta, \lambda} \theta \\
& \text { s.t. }-y+Y \lambda \geq 0 \\
& \theta \bullet x_{i}-X \lambda \geq 0 \\
& \lambda \geq 0
\end{aligned}
$$

For a given set of feasible $\lambda$ values, the left-hand-side values of input-and output-related constraints specify a production point within the production possibility set. The model seeks a production possibility set point which offers minimum output levels of $D M U_{j 0}$, while using as low a proportion of its input levels as possible. With the subscript * denoting optimal values, the $j_{0} D M U$ is DEA-efficient if and only if $\lambda_{0}^{*}=1$. If $\lambda_{0}^{*} \leq 1$ then the $j_{0} D M U$ is DEAinefficient. $\lambda_{0}^{*}$ is a measure of the radial DEA efficiency of $D M U_{j 0}$.

DEA can be carried out in various forms based on the market conditions of the DMU. As a general rule of thumb, in competitive markets, the DMUs are output-oriented, since we have assumed that inputs are under the control of the DMU, which aims to maximise its output - subject to market demand, which is outside the control of the DMU. The outputoriented technically efficient scores are estimated in this paper.

\subsection{Malmquist Productivity Index}

The Malmquist Productivity Index (MPI) is a valuable tool for analysing panel data set for monitoring productivity growth. Following Caves et al. [39], an output-based Malmquist Productivity Index with observation $k$ between time period $t$ (base period) and $t+1$ is

$M_{t, k}=\frac{E_{t, k(t+1)}}{E_{t, k(t)}}$

where $E_{t, k(t)}$ and $E_{t, k(t+1)}$ are output effiency scores relating observations in period $\mathrm{t}$ and $\mathrm{t}+1$, respectively, to a period t technology. $M_{t, k}$ measures the productivity change between period $\mathrm{t}$ and $\mathrm{t}+1$. Productivity declines if $M_{t, k}<1$, remains unchanged if $M_{t, k}=1$, and improves if $M_{t, k}>1$.

Färe et al. [45] proposed defining the output-oriented Malmquist Productivity Index as a geometric mean of: 
$M_{t+1, k}=\left[\frac{E_{t, k(t+1)}}{E_{t, k(t)}} \frac{E_{t+1, k(t+1)}}{E_{t+1, k(t)}}\right]^{1 / 2}$

Morever, the Malmquist Productivity Index can be divided into two mutually exclusive components

$M_{t+1, k}=\frac{E_{t+1, k(t+1)}}{E_{t, k(t)}}\left[\frac{E_{t, k(t+1)}}{E_{t, k(t)}} \frac{E_{t+1, k(t+1)}}{E_{t+1, k(t)}}\right]^{1 / 2}$

The first part is a catching up index that shows the relative change in efficiency between the periods. The second part of Eqn. 5 is the frontier productivity index that means the change of technical efficiency.

\subsection{Selection of indicative input/output variables}

In using DEA, multiple input and output factors can be considered simultaneously to determine the efficiency scores. The selected input and output variables are first summarised by reviewing the relevant literature and consulting with the management of the chain stores. Then the variables are operationalised according to the service distribution model. There are two input variables: labour and capital. Labour consists of the number of staff and the store manager's tenure year. Operating expenses represent the capital. Sales margin is the output variable. The input variables are used to produce a set of distribution services that relate to the sales margin. To meet the requirements of DEA, the minimum number of DMUs is greater than three times the number of inputs-plusoutputs (Walter et al. [50]). The input variables should be positive numbers and positively related to outcomes. The inventory cost is determined to be the main important proxy measure of distribution service after consulting with managers.

As shown in Figure 1, the raw inputs are allocated to obtain the intermediate outputs (distribution service) in Stage 1. In Stage 2, the intermediate output becomes input and used to produce the maximum final output (sales margin).

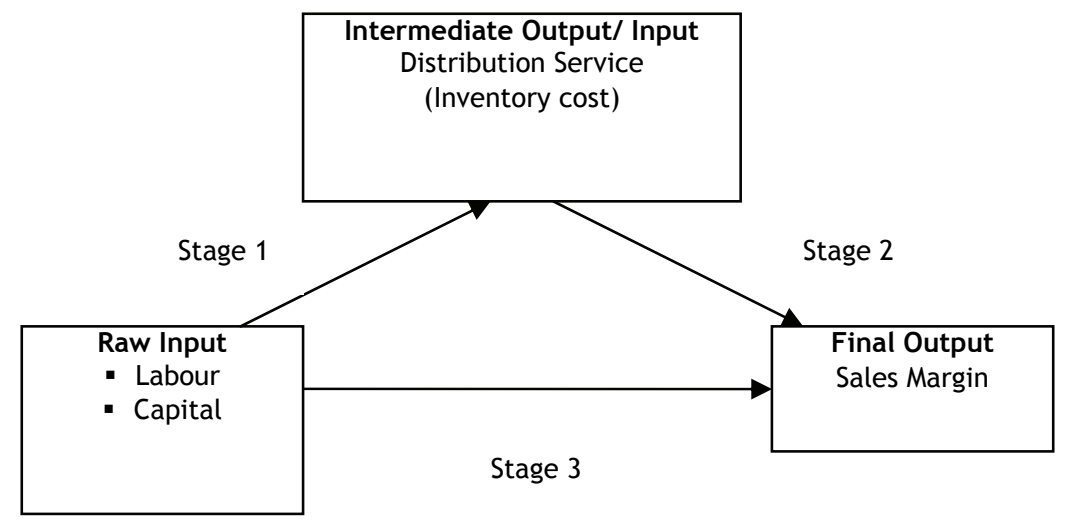

Figure 1: Triangular model

According to the limitation of isontonicity, Kao et al. [46] suggested that the correlation matrix can be used for eliminating the irrelevant variables. This investigation will test the relationship of those input/output variables.

\subsection{Data}

Data were collected from twenty 7-11 convenience stores located in the southern 
metropolitan area of Taiwan, and consisted of annual observations for the years 1998 through 2005. All 20 stores were units within one chain, and were therefore suitable for internal evaluation.

\subsection{Analysis of efficiency scores, efficiency ranking, and slack analysis}

After determining the input/output variables, the efficiency score for each store is calculated. The data for inputs and outputs of 20 convenience stores for eight years were compiled. DEA was applied to this data to establish an efficiency score for each store, and stores were ranked accordingly. We also performed slack analysis in this section.

We use correlation analysis to verify the relationships among these three stages. The efficiency score for each store from 1998 to 2005 is estimated to calculate the MPI, and the stores making great progress will be identified. The MPI will be decomposed into CIE and FPI to distinguish where the main improvement in efficiency comes from. The Management Matrix can be mapped out according to the efficiency score and MPI.

\section{EMPIRICAL RESULTS}

An intercorrelation matrix in Table 1 shows the relationship of variables used in this investigation. All four input indicators are taken into consideration without following the distribution service system. The results show that the input and output variables used in this research meet the requirements of the DEA model.

\begin{tabular}{|l|r|l|l|l|l|}
\hline & $\begin{array}{l}\text { Sales } \\
\text { margin }\end{array}$ & $\begin{array}{l}\text { Number of } \\
\text { employees }\end{array}$ & $\begin{array}{l}\text { Operating } \\
\text { expenses }\end{array}$ & $\begin{array}{l}\text { Manager's } \\
\text { tenure } \\
\text { years }\end{array}$ & $\begin{array}{l}\text { Inventory } \\
\text { cost }\end{array}$ \\
\hline Sales margin & 1.00 & & & & \\
\hline Number of employees & $.912^{\mathrm{a}}$ & 1.00 & & & \\
\hline Operating expenses & $.626^{\mathrm{a}}$ & $.568^{\mathrm{a}}$ & 1.00 & & \\
\hline Manager's tenure year & .237 & .147 & .062 & 1.00 & \\
\hline Inventory cost & $.827^{\mathrm{a}}$ & $.854^{\mathrm{a}}$ & $.477^{\mathrm{a}}$ & .343 & 1.00 \\
\hline
\end{tabular}

a $p<0.05$, two-tailed test

\section{Table 1: Correlation matrix}

The relative efficiency scores of the convenience stores analysed in 2005 are presented in Table 2. The efficiency scores represent the best possible efficiency attainable by a store given its inputs and output. This score is therefore often referred to as the relative efficiency or relative productivity. The rankings in Table 2 are in hierarchical order of efficiency, starting from the most efficient and descending to the least.

The stores that have an efficiency score of 1.0 are considered to be efficient and located at the efficiency frontier. In this example, 9 stores are found to be efficient and 11 are inefficient. For those nine DMUs with efficiency scores of 1.0, Andersen et al. [47] proposed a modified version of the model based upon a comparison of efficient DMUs relative to a reference technology spanned by all other units. This $A$ and $P$ efficiency index provides a method to increase the discrimination power for every efficient DMU, and $A 1$ has the best performance. The DEA model also allows us to identify a smaller group of best performers and calculate slacks, which specify the amount by which an input or output must be improved for the unit to become efficient. For instance, since A17 is the least efficient unit (efficiency score=0.756), its smaller group of benchmarking targets or role models are A10, 
A1, A18, and A4 (see Table 2). Therefore, for A17, it would have to emulate those four units.

\begin{tabular}{|c|c|c|c|c|c|c|c|c|}
\hline Store ID & $\mathrm{TE}_{\mathrm{CRS}}$ & $T E_{\mathrm{VRS}}$ & SE & RTS & $\begin{array}{l}\text { Benchmarking } \\
\text { group }\end{array}$ & Frequency & $\begin{array}{r}\text { A and } P \\
\text { Efficiency } \\
\text { Index }\end{array}$ & Ranking \\
\hline A1 & 1.000 & 1.000 & 1.000 & - & $\mathrm{A} 1$ & 9 & 1.561 & 1 \\
\hline A18 & 1.000 & 1.000 & 1.000 & & A18 & 9 & 1.200 & 2 \\
\hline A6 & 1.000 & 1.000 & 1.000 & & A6 & 7 & 1.154 & 3 \\
\hline A10 & 1.000 & 1.000 & 1.000 & & A10 & 9 & 1.100 & 4 \\
\hline A5 & 1.000 & 1.000 & 1.000 & & A5 & 4 & 1.088 & 5 \\
\hline A19 & 1.000 & 1.000 & 1.000 & & A19 & 7 & 1.053 & 6 \\
\hline A15 & 1.000 & 1.000 & 1.000 & & A15 & 1 & 1.029 & 7 \\
\hline A4 & 0.923 & 1.000 & 0.923 & IRS & A4 & 5 & 0.923 & 8 \\
\hline A7 & 0.870 & 1.000 & 0.870 & IRS & A7 & 4 & 0.870 & 9 \\
\hline A11 & 0.864 & 0.985 & 0.877 & DRS & A10 & 0 & 0.864 & 10 \\
\hline A20 & 0.980 & 0.981 & 0.999 & IRS & $\mathrm{A} 19, \mathrm{~A} 18, \mathrm{~A} 10, \mathrm{~A} 5$ & 0 & 0.980 & 11 \\
\hline$A 2$ & 0.967 & 0.975 & 0.992 & IRS & $\begin{array}{l}\mathrm{A} 18, \quad \mathrm{~A} 10, \quad \mathrm{~A} 5, \quad \mathrm{A6}, \\
\mathrm{A} 19\end{array}$ & 0 & 0.967 & 12 \\
\hline A9 & 0.936 & 0.972 & $0.963 \mathrm{I}$ & IRS & $\mathrm{A} 1, \mathrm{~A} 6, \mathrm{~A} 18, \mathrm{~A} 19, \mathrm{~A} 7$ & 0 & 0.936 & 13 \\
\hline A12 & 0.862 & 0.896 & 0.961 & IRS & $\mathrm{A} 1, \mathrm{~A} 6, \mathrm{~A} 18, \mathrm{~A} 19, \mathrm{~A} 7$ & 0 & 0.862 & 14 \\
\hline$A 3$ & 0.834 & 0.895 & $0.931 \mathrm{I}$ & IRS & $\mathrm{A} 18, \mathrm{~A} 6, \mathrm{~A} 4, \mathrm{~A} 7, \mathrm{~A} 1$ & 0 & 0.834 & 15 \\
\hline A8 & 0.868 & 0.873 & 0.995 & IRS & 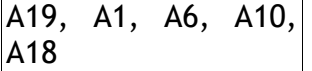 & 0 & 0.868 & 16 \\
\hline A14 & 0.850 & 0.854 & 0.995 & DRS & $\mathrm{A} 1, \mathrm{~A} 5, \mathrm{~A} 10, \mathrm{~A} 19$ & 0 & 0.850 & 17 \\
\hline A16 & 0.801 & 0.842 & 0.951 & IRS & $\mathrm{A} 6, \mathrm{~A} 1, \mathrm{~A} 10, \mathrm{~A} 4$ & 0 & 0.801 & 18 \\
\hline A13 & 0.762 & 0.837 & 0.910 & IRS & $\mathrm{A} 10, \mathrm{~A} 1, \mathrm{~A} 18, \mathrm{~A} 4$ & 0 & 0.762 & 19 \\
\hline A17 & 0.731 & 0.756 & 0.967 & IRS & $\mathrm{A} 10, \mathrm{~A} 1, \mathrm{~A} 18, \mathrm{~A} 4$ & 0 & 0.731 & 20 \\
\hline Mean & 0.912 & 0.943 & 0.967 & & & & & \\
\hline
\end{tabular}

Note: A and P Efficiency Index = Andersen and Peterson Efficiency Index [47]

Table 2: Relative efficiency scores of 20 sample stores in 2005

Table 3 is the input and output slack computed by DEA for A17 and A14. For A17 to become efficient, it must decrease the number of employees by 0.114 (that is, reducing the parttime working hours), while maintaining its current level of output. A14 must decrease its inventory cost by NT (National Taiwanese) 41,000 dollars to become more efficient (see Table 3).

\begin{tabular}{|c|c|c|c|c|c|}
\hline \multirow{2}{*}{ Store ID } & $\begin{array}{l}\text { Operating } \\
\text { expenses }\end{array}$ & $\begin{array}{l}\text { Manager's } \\
\text { tenure } \\
\text { years }\end{array}$ & $\begin{array}{l}\text { Number of } \\
\text { employees }\end{array}$ & $\begin{array}{l}\text { Inventory } \\
\text { cost }\end{array}$ & Sales margin \\
\hline & $\begin{array}{l}\text { (NT 1,000 } \\
\text { dollars) }\end{array}$ & (year) & (person) & $\begin{array}{l}\text { (NT 1,000 } \\
\text { dollars) }\end{array}$ & $\begin{array}{l}\text { (NT 1,000 } \\
\text { dollars) }\end{array}$ \\
\hline A17 & 558 & 8 & 5 & 900 & 468 \\
\hline Slack & 0 & 0 & 0.114 & 0 & 0 \\
\hline A14 & 544 & 9 & 7 & 1100 & 623 \\
\hline Slack & 0 & 0 & 0 & 41 & 0 \\
\hline
\end{tabular}

Table 3: Unit A17 and A14 benchmarking goals in 2005 
The correlation between efficiency scores in the three stages is examined as, shown in Figure 2. For Stage 1 and Stage 3, the 0.586 Spearman correlation $(p$-value $=0)$ indicates that those generating intermediate output efficiency in stores are also good at maximising the sales margin per unit of input variables. Significant positive correlations between Stage 2 and Stage 3 are found (Spearman correlation $=0.566, p$ - value $=0$ ), which means stores that transform raw inputs efficiently into final outputs are also efficient at transforming intermediate outputs into final output. For Stage 1 and Stage 2, there is no evidence of statistical linkage between transforming raw inputs into intermediate outputs, and transforming intermediate inputs into final output (Spearman correlation $=0.062, p$-value $=$ 0.794). Stores 18 and 19, for example, which do not perform as well in transforming raw inputs into intermediate outputs (Stage 1) turn out to be relatively better performers in transforming intermediate outputs into sales margin (Stage 2). This implies that these two stores use excessive levels of labour and capital, but such services are appreciated by customers, as indicated by high levels of sales margin.

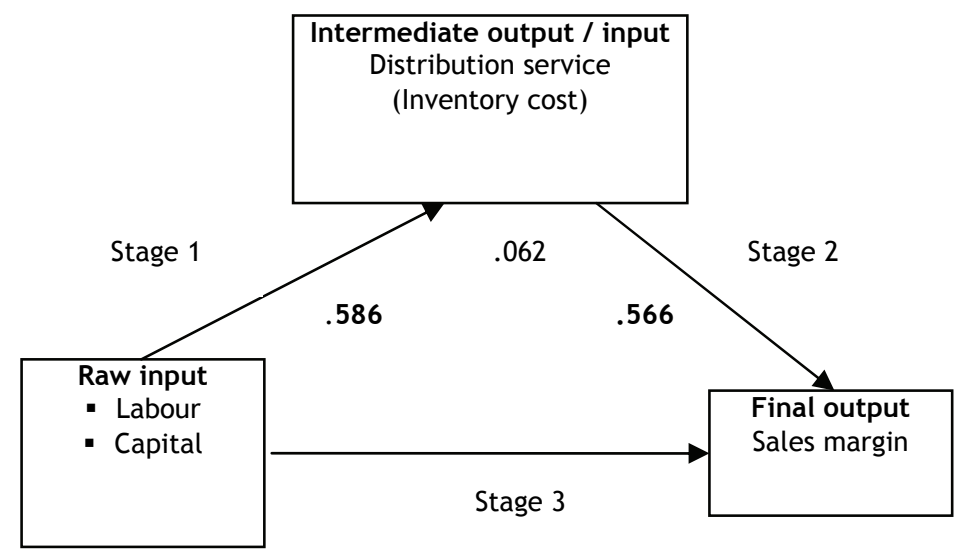

Figure 2: Spearman correlation of DEA efficiency scores in triangular model

Now consider the findings presented in Table 4 . The results indicate that the eight stores with an MPI greater than 1 have improved their managerial efficiency over the past eight years, led by A1. The remaining 12 stores have an MPI less than 1 , which means that they did not improve on efficiency.

Table 5 lists the correlation coefficients between the Malmquist productivity index and the following variables: relative efficiency in 1998, relative efficiency in 2005, frontier productivity index from 1998 to 2005, and catching up index from 1998 to 2005. The results show that the efficiency changes of these 20 stores during the previous eight years are positively correlated with a shift in frontiers and catching up efficiency during the eight years. A shift in the frontier is interpreted as a shift in the rate of learning (Rouse et al. [37]). Lapré et al. [48] explore a similar effect by distinguishing between operational learning and conceptual learning, which represent learning processes (changes in efficiency) as well as learning systems (shifts in the frontier) respectively. The results in Table 5 suggest that the convenience chain stores have achieved gains in both efficiency and learning.

However, the efficiency change is negatively correlated with relative efficiency in 1998. This signifies that between 1998 and 2005, those who made great improvements in efficiency were those with poor relative efficiency in 1998. For example, A1, A15, A18, A4, and $A 11$ had a lagging relative efficiency in 1998, but made great improvements over the next eight years. In contrast, A20, A2, A7, and A17 had a good relative efficiency in 1998, but few efficiency changes were made in the next eight years. 


\begin{tabular}{|l|l|l|l|l|l|}
\hline Store ID & $\mathrm{TE}_{1998}$ & $\mathrm{TE}_{2005}$ & CIE1998 $\rightarrow 2005$ & FPI & MPI \\
\hline A1 & 0.597 & 1.000 & 1.675 & 1.671 & 2.800 \\
\hline A15 & 0.852 & 1.000 & 1.174 & 1.116 & 1.310 \\
\hline A18 & 0.884 & 1.000 & 1.132 & 1.112 & 1.258 \\
\hline A4 & 0.876 & 0.923 & 1.053 & 1.027 & 1.082 \\
\hline A11 & 0.818 & 0.864 & 1.056 & 0.995 & 1.050 \\
\hline A9 & 0.952 & 0.936 & 0.983 & 1.042 & 1.023 \\
\hline A12 & 0.863 & 0.862 & 0.998 & 1.025 & 1.023 \\
\hline A19 & 1.000 & 1.000 & 1.000 & 1.011 & 1.011 \\
\hline A5 & 1.000 & 1.000 & 1.000 & 0.995 & 0.995 \\
\hline A6 & 1.000 & 1.000 & 1.000 & 0.987 & 0.987 \\
\hline A8 & 0.876 & 0.868 & 0.991 & 0.988 & 0.979 \\
\hline A10 & 1.000 & 1.000 & 1.000 & 0.941 & 0.941 \\
\hline A16 & 0.830 & 0.801 & 0.966 & 0.974 & 0.940 \\
\hline A20 & 1.000 & 0.980 & 0.980 & 0.955 & 0.936 \\
\hline A2 & 1.000 & 0.967 & 0.967 & 0.942 & 0.910 \\
\hline A3 & 0.864 & 0.834 & 0.965 & 0.853 & 0.822 \\
\hline A13 & 0.870 & 0.762 & 0.876 & 0.912 & 0.798 \\
\hline A7 & 1.000 & 0.870 & 0.870 & 0.889 & 0.773 \\
\hline A14 & 0.910 & 0.850 & 0.936 & 0.818 & 0.765 \\
\hline A17 & 1.000 & 0.731 & 0.731 & 0.812 & 0.594 \\
\hline Mean & 0.910 & 0.912 & 1.018 & 1.003 & 1.005 \\
\hline & & & & & \\
\hline
\end{tabular}

Table 4: Efficiency change of 20 sample stores from 1998 to 2005

\begin{tabular}{|l|c|}
\hline Efficiency & $\begin{array}{c}\text { Malmquist productivity index } \\
\text { from } 1998 \text { to } 2005\end{array}$ \\
\hline Relative efficiency in $1998\left(\mathrm{TE}_{1998}\right)$ & $-0.451^{\mathrm{a}}$ \\
\hline Relative efficiency in $2005\left(\mathrm{TE}_{2005}\right)$ & $0.600^{\mathrm{b}}$ \\
\hline Frontier Productivity Index (FPI) from 1998 to 2005 & $0.987^{\mathrm{b}}$ \\
\hline Catching-up Index (CIE) from 1998 to 2005 & $0.935^{\mathrm{b}}$ \\
\hline
\end{tabular}

a $p$-value $<0.05 ;$ b $p$-value $<0.01$

Table 5: Coefficients of correlation between efficiency change and efficiency of the 20 convenience stores

In Figure 3, the horizontal axis represents the values of relative efficiency $\left(\mathrm{TE}_{2005}\right)$ for measuring the operating efficiency. A store with a higher operating efficiency value has an excellent operating performance at present, which also means the store has greater competitiveness. The vertical axis measures efficiency changes for the period 1998 to 2005, which is the figure of MPI. A smaller value indicates a store with a slower pace of progress over the past eight years, and therefore one that is regarded as having less potential power of sustained development. The 20 sample stores can be classified into five categories as follows: 


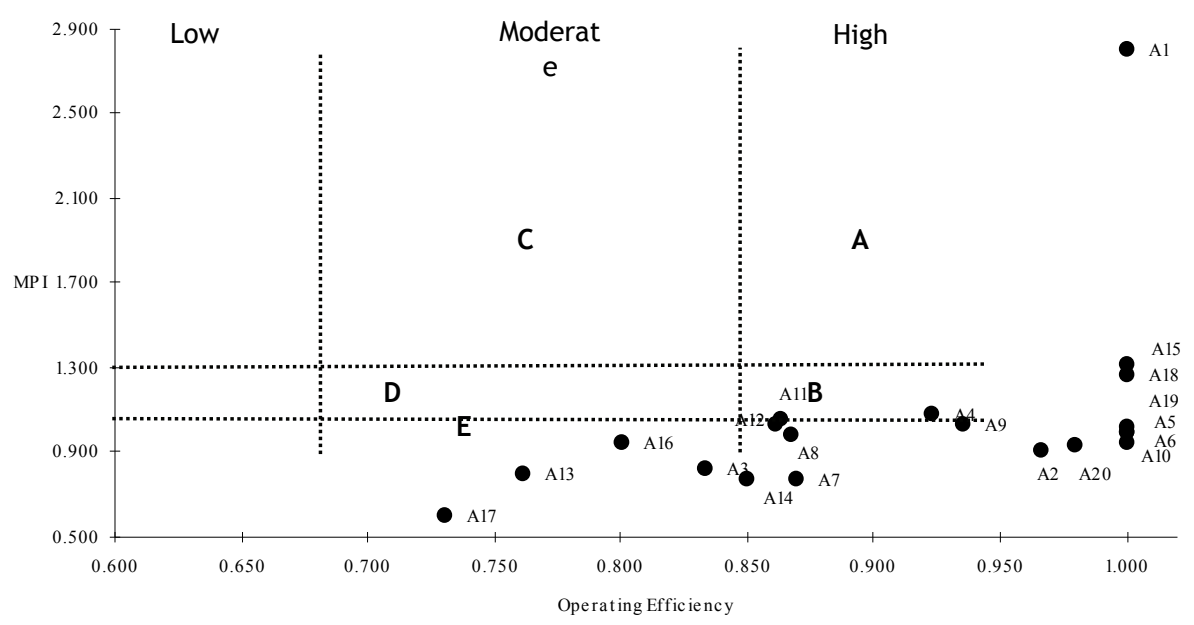

Figure 3: Management matrix of 20 sample stores

Group A represents stores with high competitiveness and with good progress in a competitive improvement. A1, A15, A18, A19, A4, and A9 are included in this group. These stores have a relative efficiency above 0.9 and an efficiency change above 1.0. The results signify that these stores have the right operating policy and operating efficiency. Group B consists of stores with high competitiveness but slow improvement progress. A5, A6, A10, $\mathrm{A} 20$, and $\mathrm{A} 2$ have a relative efficiency above 0.9 and an efficiency change value between 1.0 and 0.9. Presently, these five stores operate quite ordinarily, but have made slow progress in the past eight years. They need to make a breakthrough to maintain their competitive advantages. A11 and A12 belong to Group C. In this group, the relative efficiency score is between 0.7 and 0.9 , and MPI is greater than 1.0. It shows that the competitiveness of these two stores is strengthening gradually. Group D represents those stores with moderate degree of competitiveness and slow progress. There are six stores with values of relative efficiency between 0.7 and 0.8 and MPI scores between 0.7 and 0.9 . A17, with a moderate degree of operating efficiency and backward progress represents the last group $\mathrm{E}$.

\section{MANAGERIAL IMPLICATIONS}

Productivity improvement is the key for managers, since investors and other stakeholders are interested in the firm's financial performance. Retail productivity is a multidimensional concept, as several input and output factors impact the performance of a store. The outcome of a store should be compared with the performance of comparable stores. This makes the retail productivity issue a complex and challenging one.

The analysis of this paper demonstrates that DEA can be used as a method of relative performance evaluation using multiple inputs and outputs, which enables managers to identify the best and worst performers in a retail/distribution environment. DEA provides diagnostic information to managers for improving the underperforming units. The slacks serve as guiding posts, and management has the flexibility of achieving maximum efficiency by either increasing outputs or decreasing inputs, or both.

Productivity in sales margins arising from usage of capital and labour (Stage 3 ) is linked to the efficient distribution service system (Stage 1). Once the intermediate point is set up, the stores are more or less equally efficient at actualising them into sales margins (Stage 2). Stage 1 should therefore be the major focus for retail outlet success. 
The Malmquist analysis is provided by illustrating the annual change of individual stores for the purpose of monitoring. The results reveal that efficiency and learning improvements are the key for stores in a convenience chain. Porter [49] refers to a productivity frontier of operational effectiveness that shifts in response to competitive intensities. Maintaining relative efficiency by keeping pace with shifts in technology is a challenge for companies. Convenience stores' managers should consider technology change for improving overall productivity. The Malmquist Productivity Index is also useful to managers, allowing them to focus on competitiveness, to monitor the pace of progress of each store, as well as to manage the whole company.

\section{CONCLUSION}

To survive in the highly competitive environment of Taiwan, convenience stores' managers should pay much more attention to their performance. This paper has shown that DEA can be an effective technique to assist managers in evaluating productivity. Store managers can also make use of DEA to identify slack scores to improve efficiency. The Malmaquist Porductivity Index was shown to be a method to assist management in monitoring the change of yearly performance for individual stores, and the map (based on the results) was provided to aid management in examining the competitiveness and operating policy of the entire convenience store chain.

This paper makes three major contributions. First, it is suggested that DEA can serve as both an analysis of facets for identifying the peer group as well as slack statistics to aid in setting benchmarking goals. Second, a distribution service model is used as the output of retailing, which has hardly been applied in empirical research. Finally, the Malmquist method provides valuable insights into efficiency and the effects of learning.

The major limitation affecting this study concerns the data set. This study is based on only the convenience store sector in a southern city in Taiwan. Relying on the goodwill of retailers to share their operating data is a difficult task. Many retail firms are reluctant to provide confidential data. Stable DEA results require a large number of observations, particularly as the number of inputs and outputs is increased. Nevertheless, there is also the limitation of the minimum number of DMUs; for instance, the number of evaluated companies (DMUs) should be greater than three times the number of inputs-plus-outputs. As a result, DEA may not be appropriate when there are only a few DMUs.

Future research can compare competing stores from the same industry or across different industries - for example, hypermarkets, department stores, and supermarkets. Data from different countries can be compared in a DEA model. Making use of questionnaires to get the data from the perception of customers can also be included in DEA input, or output variables for considering the end users of the service system.

ACKNOWLEDGEMENT: The authors are grateful to the anonymous referee who made several valuable suggestions. Our paper improved considerably due to his/her suggestions.

\section{REFERENCES}

[1] Chen, W.Y. 2005. Trend Report of Taiwanese Merchandise Channel Industry in 2006 (in Chinese), Taipei: Taiwan Institute of Economic Research.

[2] Wan, C.H. 2005. Trend Report of Taiwanese Convenience Chain Stores - Fourth Quarter, 2005 (in Chinese), Taipei: Taiwan Institute of Economic Research.

[3] Donthu, N., Hershberger, E.H., and Osmonbekov, T. 2005. Benchmarking marketing productivity using data envelopment analysis, Journal of Business Research, 58(11), pp 1472-1482.

[4] Camp, R.C. 1998. Global cases in benchmarking, Milwaukee (WI): ASQ Quality Press. 
[5] McGonagle, Jr., J. and Fleming, D. 1993. New options in benchmarking, Journal of Quality and Participation, 16(4), pp 60-71.

[6] Donthu, N. and Yoo, B. 1998. Retail productivity assessment using data envelopment analysis, Journal of Retailing, 74 (1), pp 89-105.

[7] Thomas, R.R., Barr, R.S., Cron, W.L., Slocum, J.W. Jr. 1998. A process for evaluating retail store efficiency: A restricted DEA approach, International Journal of Research in Marketing, 15(5), pp 487-503.

[8] Barros, C.P. and Alves, C.A. 2003. Hypermarket retail store efficiency in Portugal, International Journal of Retail and Distribution Management, 31(11), pp 549-560.

[9] Buckin, L.P. 1978. Productivity in marketing, Chicago: American Marketing Association.

[10] Ratchford, B.T. and Brown, J.R. 1985. A study of productivity changes in food retailing, Marketing Science, 4 (Fall), pp 292-311.

[11] Ratchford, B.T. and Stoop, G.T. 1988. A model and measurement approach for studying retail productivity, Journal of Retailing, 64 (Fall), pp 241-263.

[12] Parsons, L. 1992. Productivity versus relatively efficiency in marketing: Past and future? In: Lilien, G., Laurent, G., Pras, B. (eds), Research traditions in marketing, Kluwer, Amsterdam, pp 169-196.

[13] Thurik, R. 1992. Applied econometrics and productivity analysis in marketing, In: Lilien, G., Laurent, G., Pras, B. (eds), Research traditions in marketing, Kluwer, Amsterdam, pp 197-200.

[14] Kamakura, W., Lenartowicz, T. and Ratchford, B. 1996. Productivity assessment of multiple retail outlets, Journal of Retailing, 72(4), pp 325-330.

[15] Ingene, C.A. 1982. Labor productivity in retailing, Journal of Marketing, 46 (Fall), pp 75-90.

[16] Ingene, C.A. 1984. Productivity and functional shifting in spatial retailing: Private and social perspectives, Journal of Retailing, 60 (Fall), pp 15-36.

[17] Thurik, R. and van der Wijst, N. 1984. Part-time labor in retailing, Journal of Retailing, 60 (Fall), pp 62-80.

[18] Bush, R.P., Bush, A.J., Ortinau, D.J., and Hair, J.F. Jr. 1990. Developing a behavior-based scale to assess retail salesperson performance, Journal of Retailing, 66 (Spring), pp, 119-136.

[19] Stern, L.W. and El-Ansary, A.I. 1992. Marketing channels, $4^{\text {th }}$ edition, Englewood Cliffs, NJ: Prentice Hall.

[20] Doutt, J.T. 1984. Comparative productivity performance in fast-food retail distribution, Journal of Retailing, 60 (Fall), pp 98-106.

[21] Lusch, R.F. and Moon, S.Y. 1984. An exploratory analysis of the correlations of labor productivity in retailing, Journal of Retailing, 60 (Fall), pp 37-61.

[22] Keh, H.T. 1997. The classification of distribution channel output: A review, International Review of Retail, Distribution and Consumer Research, 7(2), pp 145156. 
[23] Achabal, D.D., Heineke, J.M. and McIntyre, S.H. 1984. Issues and perspective on retail productivity, Journal of Retailing, 60 (Fall), pp 107-127.

[24] Keh, H.T. 2000. Measuring retailer performance: Towards an understanding of productivity, Journal of Targeting, Measurement and Analysis for Marketing, 9(2), pp 163-173.

[25] Betancour R.R. and Gautschi, D.A. 1990. Demand complementarities, household production, and retail assortments, Marketing Science, 9, pp 146-161.

[26] Betancour R.R. and Gautschi, D.A. 1993. The outputs of retail activities: Concepts, measurement and evidence from US census data, Review of Economics and Statistics, 75, pp 294-301.

[27] Keh, H.T. and Chu, S. 2003. Retail productivity and scale economies at the firm level: A DEA approach, Omega, 31(2), pp 75-82.

[28] Farrell, M.J. 1957. The measurement of productivity efficiency, Journal of the Royal Statistical Society Series A, 120(3), pp 253-281.

[29] Charnes, A.W., Cooper, W.W. and Rhodes, E. 1978. Measuring the efficiency of decision-making units, European Journal of Operational Research, 2(6), pp 429-444.

[30] Ho, C.T. and Zhu, D.S. 2004. Performance measurement of Taiwan's commercial banks, International Journal of Productivity and Performance Measurement, 53(5), pp 425-434.

[31] Balakrishnan, P., Desai, A. and Storbeck, J. 1994. Efficiency evaluation of retail outlet networks, Environment and Planning, 21(4), pp 477-488.

[32] Athanassopoulos, A. 1995. Performance improvement decision aid systems (pidas) in retailing organizations using data envelopment analysis, The Journal of Productivity Analysis, 6(2), pp 153-170.

[33] Li, Y., Hu, J.L. and Chiu, Y.H. 2004. Ownership and production efficiency: Evidence from Taiwanese banks, The Service Industries Journal, 24(4), pp 129-148.

[34] Keh, H.T., Chu, S. and Xu, J. 2006. Efficiency, effectiveness and productivity of marketing in services, European Journal of Operational Research, 170(1), pp 265276.

[35] Marianna, S., Jones, P., Lockwood, A. and Airey, D. 2005. Productivity in hotels: A stepwise data envelopment analysis of hotels' rooms division processes, The Service Industries Journal, 25(1), pp 61-81.

[36] Wang, F.C., Hung, W.T. and Shang, J.K. 2006. Measuring pure managerial efficiency of international tourist hotels in Taiwan, The Service Industries Journal, 26(1), pp $59-71$.

[37] Rouse, P., Putterill, M. and Ryan, D. 2002. Integrated performance measurement design: Insights from an application in aircraft maintenance, Management Accounting Research, 13(2), pp 229-248.

[38] Malmquist, S. 1953. Index numbers and indifference surfaces, Trabajos de Estadistica, 4, pp 209-242.

[39] Caves, D.W., Christensen, L.R. and Diewert, W.E. 1982. The economic theory of 
index numbers and the measurement of input, output and productivity, Econometrica, 50, pp 1078-1092.

[40] Färe, R., Grosskopf, S., Lindgren, B. and Ross, P. 1992. Productivity changes in Swedish pharmacies 1980-1989: A non-parametric Malmquist approach, The Journal of Productivity Analysis, 3(1), pp 85-101.

[41] Flegg, A.T., Allen, D.O., Field, K. and Thurlow, T.W. 2004. Measuring the efficiency of British universities: A multi-period data envelopment analysis, Education Economics, 12(3), pp 231-249.

[42] Odeck, J. 2006. Identifying traffic safety best practice: An application of DEA and Malmquist indices, Omega, 34(1), pp 28-40.

[43] Chen, S.N. 2006. Productivity changes in Taiwanese hospitals and the national health insurance, The Service Industries Journal, 26(4), pp 459-477.

[44] Şakar, B. 2006. A study of efficiency and productivity of Turkish banks in Istanbul stock exchange using Malmquist DEA, Journal of American Academy of Business, 8(2), pp 145-155.

[45] Färe, R., Grosskopf, S., Lovell, C.A.K. 1985. The measurement of efficiency of production, Boston, MA: Kluwer/Nijhoff.

[46] Kao, C., Huang, H.N. and Sueyoshi, T. 2003. Management performance evaluation data envelopment analysis (in Chinese), 1st edition, Taipei: Hwatai.

[47] Andersen P. and Petersen, N.C. 1993. A procedure for ranking efficient units in data envelopment analysis, Management Science, 39(10), pp 1261-1264.

[48] Lapré, M.A., Muhkerjee, A.S. and van Wassenhove, L.N. 1999. Behind the learning curve: Linking learning activities to waste reduction, Management Science, 46, pp 587-611.

[49] Porter, M.E. 1996. What is strategy? Harvard Business Review, November-December, pp 61-78.

[50] Walter, D. and Laffy, D. 1996. Managing retail productivity and profitability, London: Macmillan. 